\title{
Effect of Copper and Iron Ions on the Sulphidizing Flotation of Copper Oxide in Copper Smelting Slag
}

\author{
Qing-qing Pan $\mathbb{D}^{1,2}$ and Hui-qing Peng ${ }^{1}$ \\ ${ }^{1}$ School of Resource and Environment, Wuhan University of Technology, Wuhan 200245, China \\ ${ }^{2}$ School of Mechanical, Shanghai Dianji University, Shanghai 201306, China \\ Correspondence should be addressed to Qing-qing Pan; panqq@sdju.edu.cn
}

Received 13 October 2017; Revised 6 December 2017; Accepted 4 January 2018; Published 11 March 2018

Academic Editor: Jun Liu

Copyright (C) 2018 Qing-qing Pan and Hui-qing Peng. This is an open access article distributed under the Creative Commons Attribution License, which permits unrestricted use, distribution, and reproduction in any medium, provided the original work is properly cited.

\begin{abstract}
The treatment of smelting slag has attracted much attention nowadays. This study investigates the influence of $\mathrm{Na}_{2} \mathrm{~S}, \mathrm{CuSO}_{4}$, and $\mathrm{FeCl}_{3}$ on sulphidizing flotation of copper oxide. The results show that a proper $\mathrm{Cu}^{2+}$ concentration can increase the sulphidizing effect of copper oxide, while $\mathrm{Fe}^{3+}$ inhibits the sulphidizing effect. Further analysis shows that $\mathrm{Cu}^{2+}$ ions can reduce the surface potential, increase the $\mathrm{S}^{2-}$ adsorption, then generate more polysulfide, and therefore promote the sulphidizing flotation. However, $\mathrm{Fe}^{3+}$ ions would increase the surface potential, reduce the $\mathrm{S}^{2-}$ adsorption, generate more sulfur element, and therefore inhibit the sulphidizing flotation.
\end{abstract}

\section{Introduction}

Nowadays, more than $97 \%$ copper in the world is produced by pyrometallurgical smelting, and a large amount of smelting slag is produced at the same time. The copper smelting slag mainly consists of products crystallized from high-temperature molten material, and their compositions are very complicated. The separation of the slag is quite difficult, and the depleted residue can still contain a certain amount of heavy metal compounds [1-4]. If these wastes are not properly treated and directly discharged into the natural environment, they would cause not only the waste of resources but also serious pollution of the environment.

The Ruolanda slag is mainly composed of matte $[5,6]$, along with a small amount of copper oxide, copper, and traces of diffluent copper salts. The main constituents that need to be recycled are matte, copper oxide, and copper, and the most commonly used technique for the recycling is flotation $[7,8]$. In the past, most researches about the recycle and utilization of the copper slag were conducted to optimize the flotation agents, processes, and procedures in the flotation process of copper recycling [9-11]. However, the composition of copper smelting slag differs from that of ordinary copper minerals, and the flotation mechanism of copper oxide and copper in the process has been rarely reported in the published literatures.

The researches on flotation mechanism mainly focus on the interaction between ions and minerals in the pulp and the adsorption behavior between the metal ions and the minerals [12-14]. Wei et al. studied the influence of metal ions (such as $\mathrm{Ca}^{2+}, \mathrm{Mg}^{2+}, \mathrm{Fe}^{2+}, \mathrm{Fe}^{3+}, \mathrm{Cu}^{2+}, \mathrm{Zn}^{2+}$, and $\mathrm{Al}^{3+}$ ) in the pulp on the chalcopyrite and galena floatability [15]. Yuan et al. investigated the influences and mechanism of metal ions on the flotation of molybdenite by flotation experiments and measurements of zeta potential [16]. Multiple unavoidable metal ions also exist in the copper smelting slag pulp, mainly consisting of iron and copper ions. Different metal ions have different impacts on various flotation targets, activation, or inhibition. Deng et al. [17]. investigated the adsorption behaviors of copper ions on the chalcopyrite surfaces and found a new viewpoint about self-activation of the copper ions. The same group also studied the types, structures, and compositions in natural pure chalcopyrite and measured the total concentrations of $\mathrm{Cu}\left(\mathrm{C}_{\mathrm{CuT}}\right)$ and $\mathrm{Fe}\left(\mathrm{C}_{\mathrm{FeT}}\right)$ released from the inclusions $[18,19]$. Zhang et al. investigated the effect of $\mathrm{Fe}$ (III) ions on the flotation of spodumene, albite, and quartz 
minerals using sodium oleate (NaOL) and found $\mathrm{Fe}$ (III) as an activator for the flotation [20].

In this study, the effects of $\mathrm{Cu}^{2+}$ and $\mathrm{Fe}^{3+}$ on the sulphidizing and flotation of copper oxide in copper smelting slag are systematically investigated based on the analysis of chemical composition and phase of copper smelting slag. The interaction mechanism of the $\mathrm{Cu}^{2+}$ and $\mathrm{Fe}^{3+}$ on the copper oxide surface is studied.

\section{Experimental}

2.1. Material Preparation. The raw material used in this experiment is Ruolanda copper smelting slow cooling slag. The main composition of the slag is shown in Table 1 . The percentage of the copper compounds is shown in Table 2.

The raw slag was crushed and ground, and particles with a size of around 0.1 to $0.074 \mathrm{~mm}$ were filtered out. Copper oxide with a relatively high purity was selected using a microscope, and the samples were examined with X-ray diffraction (XRD). Figure 1 shows the XRD pattern of the selected particles. The main peaks of the XRD patterns of particles were identified as copper oxide according to the JCPDS cards. Although the material contains other impurities, their concentration was relatively low. The chemical test confirms the copper grade was $76.28 \%$, and the percent of copper oxide should be more than 95\%. The determination results by XRF (PANalytical Axios Advanced) are shown in Table 3. The obtained copper oxide was used in the following experiments.

2.2. Flotation Experiments. The flotation experiments were carried out using a RK/FGC-35 mL groove-type flotation machine. $2 \mathrm{~g}$ of $\mathrm{CuO}$ was added into $25 \mathrm{~mL} \mathrm{Na} \mathrm{N}_{2} \mathrm{~S}(0.156 \mathrm{~g} / \mathrm{L})$ aqueous solution at different $\mathrm{pH}$ values. The flotation temperature was room temperature. The stirring speed was $1000 \mathrm{r} / \mathrm{min}$, and the concentration of the collector butylxanthate and compound higher alcohols frother 2\# pine camphor oil was $0.167 \mathrm{~g} / \mathrm{L}$ and $0.027 \mathrm{~g} / \mathrm{L}$, respectively. The flowsheet of flotation process is shown in Figure 2. The $\mathrm{pH}$ value which produced the highest recovery was applied in the following experiments. The final concentrates and tailings were filtered, dried, and then weighed and tested to calculate the recovery rate.

2.3. Zeta Potential Measurement. The zeta potential of the mineral surface was measured using BDL-B zeta potential particle size analyzer, in an aqueous solution of $0.025 \mathrm{~g} / \mathrm{L}$ $\mathrm{CuSO}_{4}, 0.156 \mathrm{~g} / \mathrm{L} \mathrm{Na} 2 \mathrm{~S}$, and $0.0162 \mathrm{~g} / \mathrm{L} \mathrm{FeCl}_{3}$. CuO particles were milled to obtain a particle size less than $38 \mu \mathrm{m} .0 .05 \mathrm{~g}$ particles were added in a $100 \mathrm{~mL}$ beaker. Deionized water, $\mathrm{CuSO}_{4}, \mathrm{Na}_{2} \mathrm{~S}$, and $\mathrm{FeCl}_{3}$ were added as given in Table 4 and diluted with deionized water to $50 \mathrm{~mL}$. $\mathrm{HCl}$ and $\mathrm{NaOH}$ solutions were used to adjust the $\mathrm{pH}$ value. After that, the solutions were magnetically stirred for about 5 minutes and then the zeta potential measurements were carried out.

2.4. ICP and XPS Measurements. The $\mathrm{CuO}$ particles were ground into small particles with size less than $74 \mu \mathrm{m} .2 .5 \mathrm{~g}$ of the particles was added to $100 \mathrm{~mL}$ solution to conduct the
TABLE 1: Composition of the Ruolanda copper smelting slag (wt.\%). \begin{tabular}{llllllllll}
\hline $\mathrm{Cu}$ & $\mathrm{Fe}$ & $\mathrm{S}$ & $\mathrm{Zn}$ & $\mathrm{Pb}$ & $\mathrm{SiO}_{2}$ & $\mathrm{Al}_{2} \mathrm{O}_{3}$ & $\mathrm{CaO}$ & $\mathrm{MgO}$ & Others
\end{tabular} $\begin{array}{llllllllll}4.07 & 42.14 & 1.71 & 0.57 & 0.09 & 23.38 & 2.52 & 5.25 & 2.74 & 17.53\end{array}$

TABle 2: Chemical composition of copper compounds in raw materials (wt.\%).

\begin{tabular}{lccccc}
\hline $\begin{array}{l}\text { Copper } \\
\text { sulfide }\end{array}$ & Copper & $\begin{array}{c}\text { Copper } \\
\text { oxide }\end{array}$ & $\begin{array}{c}\text { Diffluent } \\
\text { copper salt }\end{array}$ & $\begin{array}{c}\text { Other copper } \\
\text { compounds }\end{array}$ & Total \\
\hline 3.003 & 0.827 & 0.204 & 0.002 & 0.0334 & 4.07 \\
\hline
\end{tabular}

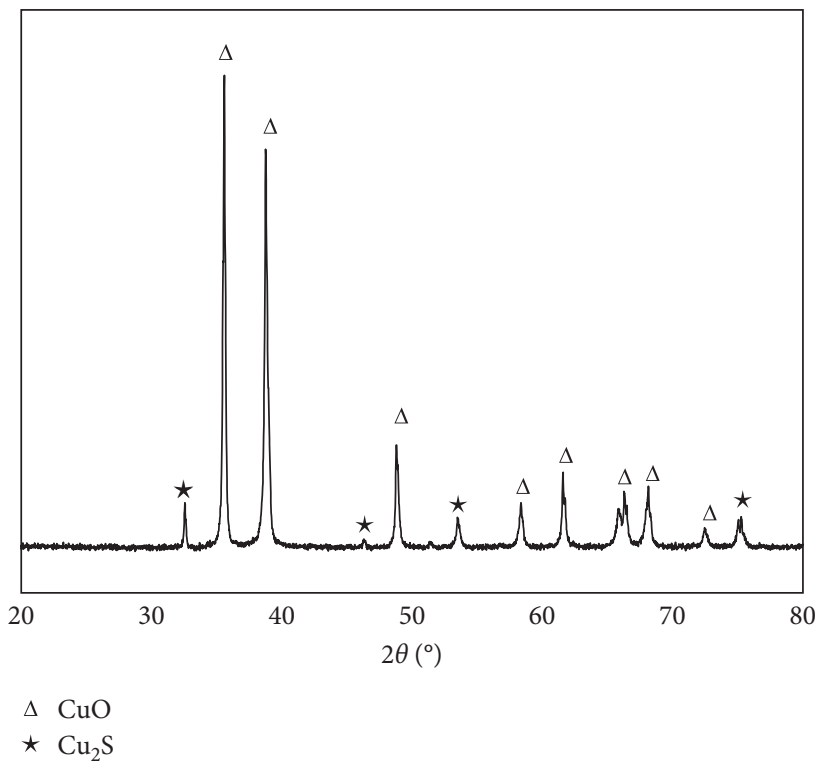

FIGURE 1: XRD pattern of the selected $\mathrm{CuO}$ particles.

leaching experiments. The stirring speed was $100 \mathrm{r} / \mathrm{min}$. After the leaching process was completed, the mixed solution was separated by centrifugation. The supernatant liquor was collected for the measurement of ion concentration using an inductively coupled plasma emission spectrometer (ICP, Optima $4300 \mathrm{DV}$ ), and the solid portion was dried and stored.

The leaching dissolution equilibrium time of copper ion, $t$, determined from the ICP ion concentration tests was set as the reaction time for the ion adsorption experiment. $2.5 \mathrm{~g}$ $\mathrm{CuO}$ particles with size less than $74 \mu \mathrm{m}$ were added into various solutions $(100 \mathrm{~mL}$ as shown in Table 3$)$ with a stirring speed of $100 \mathrm{r} / \mathrm{min}$. After reaction for $t$ minutes, the solid phase and the liquid phase were separated. The liquid phase was sealed and then tested with ICP for the ion concentration. The solid part was dried and then was characterized by X-ray photoelectron spectroscopy (XPS), together with the former solid part which was leached for $t$ minutes.

\section{Results and Discussion}

3.1. Flotation Analysis. In order to study the influence of $\mathrm{S}^{2-}$, $\mathrm{Cu}^{2+}$, and $\mathrm{Fe}^{3+}$ ions on the flotation of copper oxide, the flotation experiments with various $\mathrm{pH}$ values and different amount of $\mathrm{Na}_{2} \mathrm{~S}, \mathrm{CuSO}_{4}$, and $\mathrm{FeCl}_{3}$ were conducted. 
TABLE 3: The determination results by XRF (\%).

\begin{tabular}{lccccccrrrr}
\hline Samples & $\mathrm{CuO}$ & $\mathrm{Fe}_{3} \mathrm{O}_{4}$ & $\mathrm{Fe}_{2} \mathrm{O}_{3}$ & $\mathrm{Cu}$ & $\mathrm{Cu}_{2} \mathrm{~S}$ & $\mathrm{SiO}_{2}$ & $\mathrm{Al}_{2} \mathrm{O}_{3}$ & $\mathrm{CaO}$ & $\mathrm{MgO}^{2}$ \\
\hline 1 & 95.622 & 0.319 & 0.334 & - & 3.324 & 0.032 & 0.085 & 0.020 & 0.084 \\
2 & 96.176 & 0.419 & 0.164 & 0.091 & 2.928 & 0.100 & - & 0.073 & 0.049 \\
3 & 96.038 & 0.481 & 0.282 & 0.153 & 2.722 & 0.217 & 0.031 & - & 0.076 \\
4 & 95.811 & 0.241 & 0.091 & 0.103 & 3.216. & 0.282 & - & 0.061 & 0.195 \\
\hline
\end{tabular}

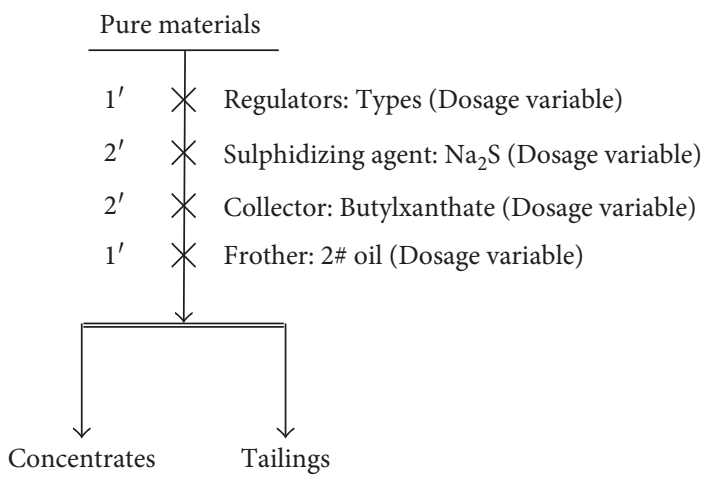

Figure 2: Flowsheet of flotation process.

TABLE 4: Various added agents for the experiments.

\begin{tabular}{lcccccc}
\hline Condition & 1 & 2 & 3 & 4 & 5 & 6 \\
\hline Agents & None & $\mathrm{Na}_{2} \mathrm{~S}$ & $\mathrm{Cu}^{2+}$ & $\begin{array}{c}\mathrm{Na}_{2} \mathrm{~S} \\
\mathrm{Cu}^{2+}\end{array}$ & $\mathrm{Fe}^{3+}$ & $\begin{array}{c}\mathrm{Na}_{2} \mathrm{~S} \\
\mathrm{Fe}^{3+}\end{array}$ \\
\hline
\end{tabular}

The results of copper oxide flotation are shown in Figure 3. The recovery of $\mathrm{CuO}$ under different $\mathrm{pH}$ conditions is shown in Figure 3(a). As shown in Figure 3(a), the recovery of copper oxide generally increases with the $\mathrm{pH}$ value and reaches the highest value of about $84.8 \%$ when the $\mathrm{pH}$ value equals 10 . The recovery slightly decreases when the $\mathrm{pH}$ value reaches 11 . The optimum $\mathrm{pH}$ value of 10 was applied for the following flotation experiments. As shown in Figure 3(b), the recovery achieved the highest value when $\mathrm{Na}_{2} \mathrm{~S}$ concentration was $0.156 \mathrm{~g} / \mathrm{L}$, indicating that proper concentration of $\mathrm{Na}_{2} \mathrm{~S}$ could improve the flotation process. $\mathrm{Na}_{2} \mathrm{~S}$ is widely exploited as an activator of sulfidizing oxide minerals [21], so insufficient sulfidization on the mineral surface cannot render the $\mathrm{CuO}$ surface adequately sulfidized. But excess $\mathrm{Na}_{2} \mathrm{~S}$ could depress the flotation because sulfide ions hold a strong reducing capacity [22], thus the potential of mineral/water interface should be reduced, with which the generation of copper xanthate species on the sulfidized mineral surface will be affected. In addition, excess sulfide-ion species may take place of the formed copper xanthate species on the sulfidized $\mathrm{CuO}$ surface because of its lower solubility product constant. Figure 3(c) shows that the maximum recovery of $91.2 \%$ was obtained when the concentration of $\mathrm{CuSO}_{4}$ was $0.025 \mathrm{~g} / \mathrm{L}$, suggesting that appropriate concentration of $\mathrm{Cu}^{2+}$ could increase the sulphidizing effect of $\mathrm{Na}_{2} \mathrm{~S}$. On the other hand, as shown in Figure 3(d), $\mathrm{Fe}^{3+}$ has a quite obvious inhibition effect for the recovery of $\mathrm{CuO}$. The recovery of $\mathrm{CuO}$ significantly decreased with the increase of $\mathrm{Fe}^{3+}$ and ultimately reached about $0 \%$.
3.2. Zeta Potential Analysis. Every ion could attach on the part surface and therefore alter its floatability. The surface electrokinetic potential could reflect the floatability of the material. Therefore, the influence of copper and iron ions on the sulphidizing and floatability of copper oxide can be investigated through the measurements of the surface electrokinetic potential.

Figure 4 shows the effect of different concentrations of $\mathrm{Cu}^{2+}$ and $\mathrm{Fe}^{3+}$ on the dependence of zeta potential on $\mathrm{pH}$ values of $\mathrm{CuO}$. When pure copper oxide was leached in pure water, the $\mathrm{pH}$ value of the solution was about 6.5. It can be seen from Figure 4 that the $\mathrm{CuO}$ zeta potential is negative in the $\mathrm{pH}$ region $3-12$ and the isoelectric point (IEP) is about 2.5 , but a maximum change was observed when the $\mathrm{pH}$ is around 9, and it upraised suddenly where $\mathrm{CuO}$ flotation recovery was near its maximum. After $\mathrm{Cu}^{2+}$ addition, the potential of $\mathrm{CuO}$ in the solution is decreased in value (less negative) and even becomes positive at $\mathrm{pH}$ around 10 , and the IEP also moved right to nearly 3.5 ; it may be because the covalent adsorption between $\mathrm{Cu}^{2+}$ ion and the $\mathrm{CuO}$ surface increases the potential of $\mathrm{CuO}$. When solution was added with $\mathrm{Fe}^{3+}$, the potential becomes more positive and remain constant with $\mathrm{pH}$ until $\mathrm{pH} 10$. This could be ascribed to the large amount of ferric hydroxide specific adsorption on the $\mathrm{CuO}$ surface [23]. Zeta potential of pure $\mathrm{CuO}$ was negative, but zeta potential of ferric hydroxide was positive, so there must be specific adsorption occurred, which made the zeta potential positive. Ferric hydroxide begins to precipitate at $\mathrm{pH}$ nearly 2.9 [23], and it may precipitate on the $\mathrm{CuO}$ surface earlier than precipitating in the solution, so the specific adsorption will continue, and the zeta potential will remain positive until the $\mathrm{pH}$ get to the IEP of ferric hydroxide itself(nearly 8).

The effect of $\mathrm{Cu}^{2+}$ and $\mathrm{Fe}^{3+}$ on the zeta potential of sulfidized $\mathrm{CuO}$ is shown in Figure 5. As can be seen from Figure 5, in the presence of $\mathrm{Na}_{2} \mathrm{~S}$, the zeta potential became further negative, which indicates that the sulfidization reaction occurred. That is because the $\mathrm{S}^{2-}$ and HS- from the hydrolyzation [24] of $\mathrm{Na}_{2} \mathrm{~S}$ are adsorbed on the $\mathrm{CuO}$ surface by chemical adsorption rather than electrostatic attraction [25]. As shown in Figure 5, due to the addition of $\mathrm{Na}_{2} \mathrm{~S}$ along with $\mathrm{Cu}^{2+}$ ions, the $\mathrm{CuO}$ potential significantly increased (became more negative) relatively to that of $\mathrm{CuO}$ but decreased (became less negative) in relation to $\mathrm{CuO}+\mathrm{Na}_{2} \mathrm{~S}$. It increased (became more negative) at $\mathrm{pH}>9$. This phenomenon demonstrated that the $\mathrm{Cu}^{2+}$ results in better sulfidization at the region from 9 to 11.5 , and more copper-sulfide films were formed on the $\mathrm{CuO}$ surface. On the opposite, $\mathrm{Fe}^{3+}$ ions have different impact on the adsorption of sulfur ions on $\mathrm{CuO}$ surface. It increased (became more negative) relative to that of $\mathrm{CuO}$ but decreased (became less negative) in relation to $\mathrm{CuO}+\mathrm{Na}_{2} \mathrm{~S}$. 


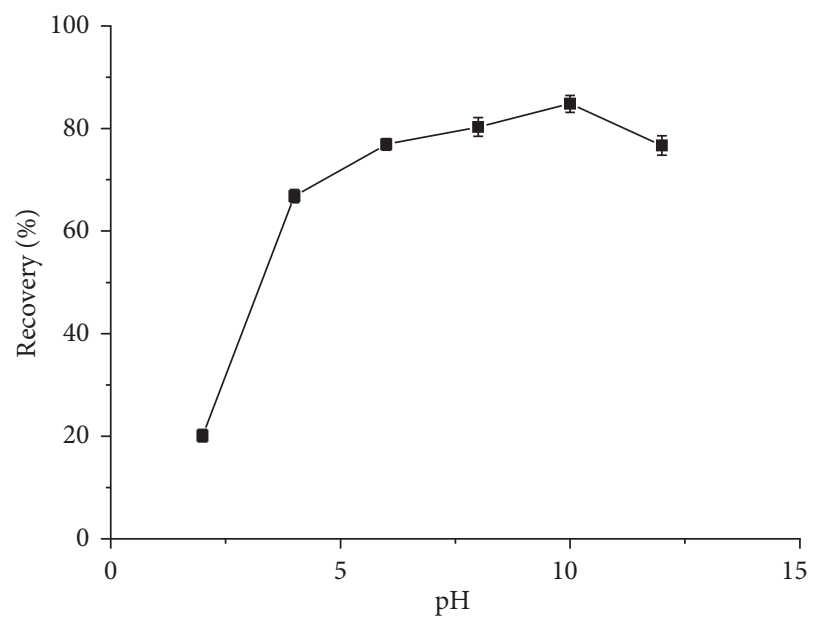

(a)

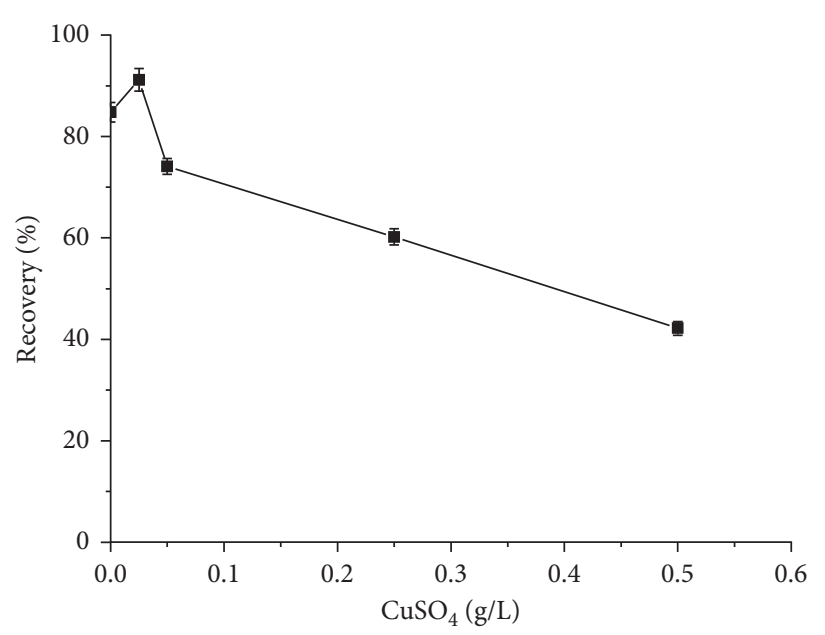

(c)

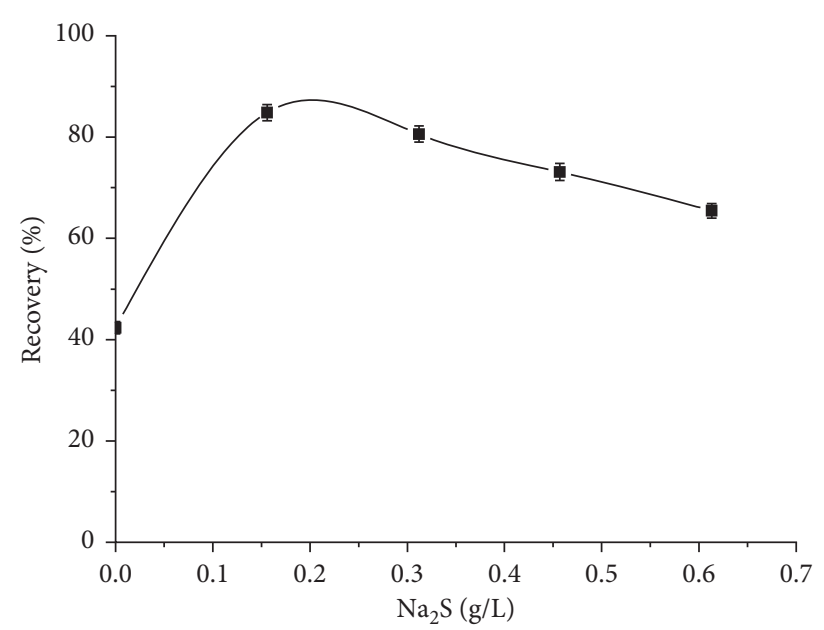

(b)

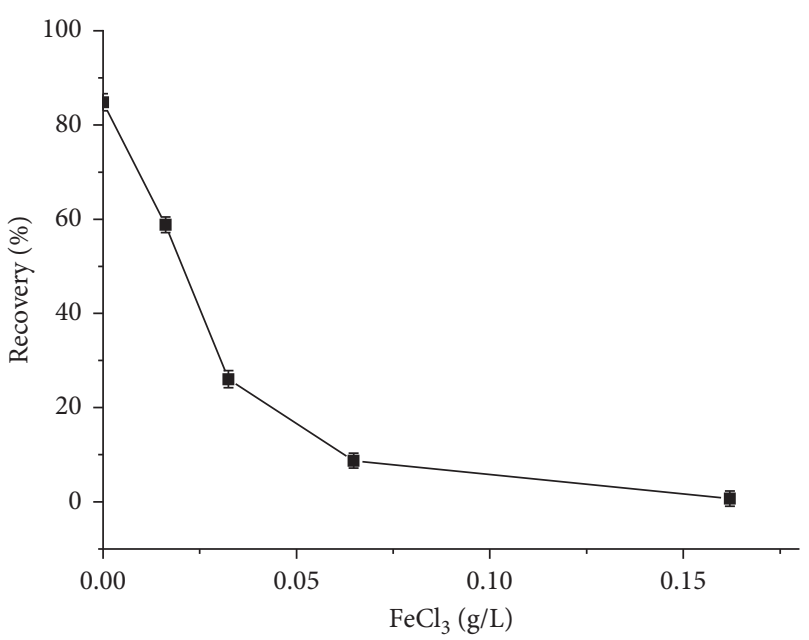

(d)

Figure 3: Recovery of $\mathrm{CuO}$ under different conditions: (a) different $\mathrm{pH}$ values $\left(\mathrm{Na}_{2} \mathrm{~S} 0.156 \mathrm{~g} / \mathrm{L}\right)$; (b) different $\mathrm{Na}_{2} \mathrm{~S}$ concentrations ( $\mathrm{pH}=10$, neither $\mathrm{CuSO}_{4}$ nor $\mathrm{Fe}_{3} \mathrm{Cl}$ addition); (c) different $\mathrm{CuSO}_{4}$ concentrations $\left(\mathrm{pH}=10, \mathrm{Na}_{2} \mathrm{~S} 0.156 \mathrm{~g} / \mathrm{L}\right.$ ); (d) different $\mathrm{Fe}_{3} \mathrm{Cl}$ concentration $(\mathrm{pH}=10$, $\left.\mathrm{Na}_{2} \mathrm{~S} 0.156 \mathrm{~g} / \mathrm{L}\right)$.

3.3. Adsorption of $\mathrm{Cu}^{2+}$ and $\mathrm{Fe}^{3+}$. The solubility of $\mathrm{CuO}$ in water is relatively low. It generally takes several hours or even days for $\mathrm{CuO}$ to reach the equilibrium of dissolution. Also, with increasing dissolution time, the dissolution rate is gradually reduced. The dissolution rate of $\mathrm{CuO}$ was measured to detect the time for obtaining the equilibrium of dissolution, which was then selected as the reaction time for the adsorption experiment.

The time-dependent solubility of $\mathrm{CuO}$ in pure water is shown in Figure 6. It can be seen from Figure 6 that the concentration of $\mathrm{Cu}^{2+}$ in the $\mathrm{CuO}$ solution increased with time, and the dissolution rate became relatively low after dissolving for $30 \mathrm{~min}$, indicating that the dissolution tended to be equilibrium. The concentration of $\mathrm{Cu}^{2+}$ after $60 \mathrm{~min}$ is similar to that after $1440 \mathrm{~min}$, and therefore, a reaction time of 30-60 min is acceptable.

The ICP results of the $\mathrm{CuO}$ solution with adsorbed ions are shown in Figure 7. From the ICP results, it can be concluded that the actual solubility of $\mathrm{CuO}$ is higher than the theoretical reference value [26]. That is because the purity of $\mathrm{CuO}$ is hard to reach $100 \%$. Trace substances and the $\mathrm{CO}_{2}$ in the air could generate salt soluble effect, which increases the solubility and dissolution rate $[27,28]$.

As shown in Figure 7, with the addition of $\mathrm{Na}_{2} \mathrm{~S}$ in the $\mathrm{CuO}$ solution, the $\mathrm{S}$ in the solution was reduced by about $86.2 \%$, indicating that $S$ was well adsorbed on the solid surface. With the presence of $\mathrm{Cu}^{2+}$ and $\mathrm{Fe}^{3+}$, the $\mathrm{S}$ concentration was further reduced, indicating that $\mathrm{Cu}^{2+}$ and $\mathrm{Fe}^{3+}$ consumed $\mathrm{S}$ or promoted the adsorption of $\mathrm{S}$ on the surface of the sample, and the $\mathrm{Fe}^{3+}$ ion had a greater effect than $\mathrm{Cu}^{2+}$ ion. Further XPS measurements should be conducted to confirm whether it was consumption or adsorption. Regarding the $\mathrm{Cu}$, the concentration of $\mathrm{Cu}$ was reduced by $83.4 \%$ with the addition of $\mathrm{Na}_{2} \mathrm{~S}$ in the $\mathrm{CuO}$ solution, indicating the existence of covalent adsorption. With further addition of $\mathrm{Na}_{2} \mathrm{~S}$, there was an increase in the concentration of $\mathrm{Cu}^{2+}$, suggesting that the $\mathrm{Na}_{2} \mathrm{~S}$ could consume part of $\mathrm{Cu}^{2+}$ and reduce adsorption of $\mathrm{Cu}^{2+}$ on the $\mathrm{CuO}$. In addition, $\mathrm{Fe}^{3+}$ in the $\mathrm{CuO}$ solution was reduced 


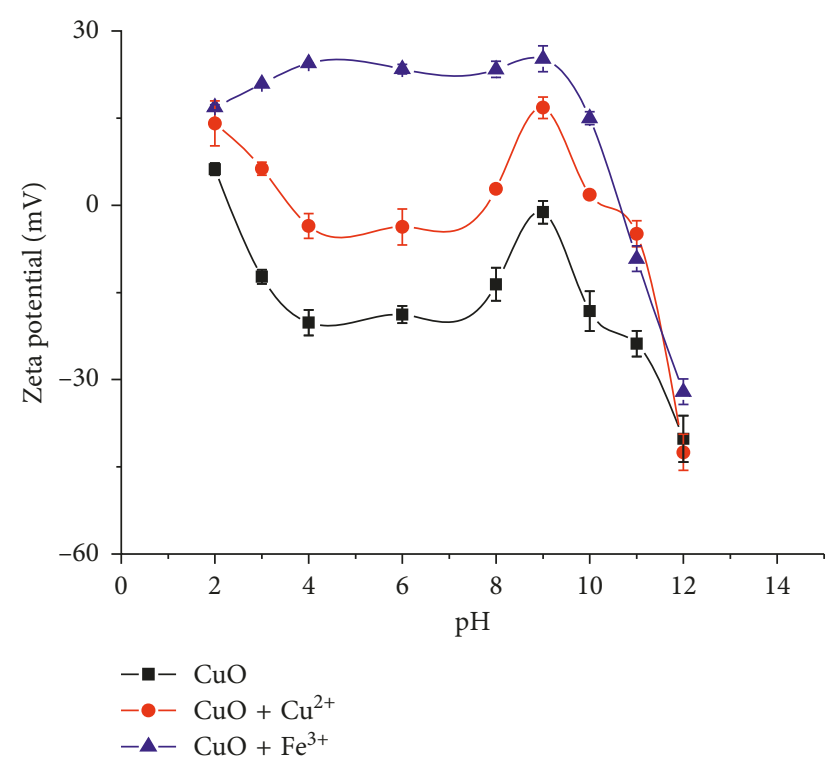

Figure 4: Effect of $\mathrm{Cu}^{2+}$ and $\mathrm{Fe}^{3+}$ ions on the zeta potential of $\mathrm{CuO}$.

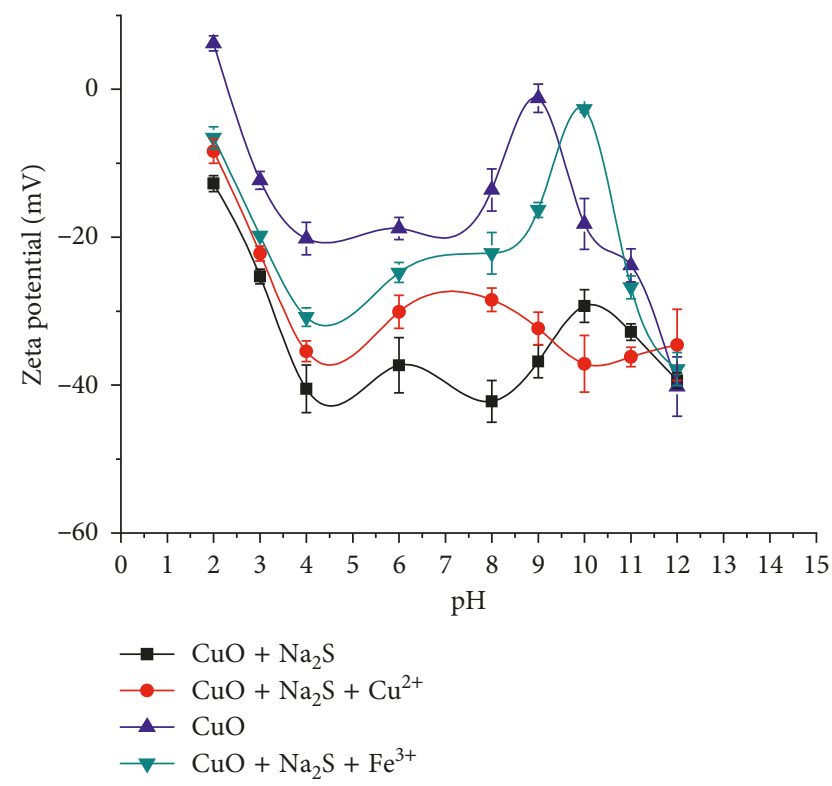

FIGURE 5: Effect of $\mathrm{Cu}^{2+}$ and $\mathrm{Fe}^{3+}$ on the zeta potential of sulfidized $\mathrm{CuO}$.

significantly by about $89.8 \%$. The reduction of $\mathrm{Fe}^{3+}$ can be ascribed to not only the adsorption of $\mathrm{Fe}^{3+}$ on the solid surface but also the consumption of $\mathrm{Fe}^{3+}$ from the redox reaction. With further addition of $\mathrm{Na}_{2} \mathrm{~S}, \mathrm{Fe}^{3+}$ concentration was further reduced to nearly zero. The redox reaction between $\mathrm{Fe}^{3+}$ and $\mathrm{S}^{2-}$ increased the consumption of $\mathrm{Fe}^{3+}$.

3.4. XPS Analysis. Figure 8 shows the full XPS spectra of $\mathrm{CuO}$ surface with and without different additions. The $\mathrm{C} 1 \mathrm{~s}$ spectrum is used as calibration data in this analysis. As is shown in Table 5 , the addition of $\mathrm{Na}_{2} \mathrm{~S}$ increased the molar percentage of $\mathrm{S} 2 \mathrm{p}$ and decreased that of $\mathrm{Cu} 2 \mathrm{p}$ and $\mathrm{O} 1 \mathrm{~s}$ due to

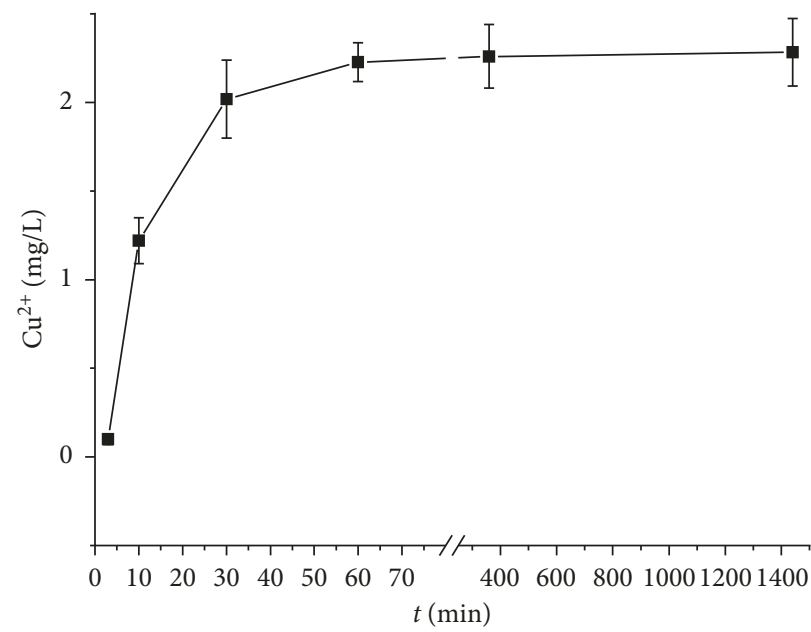

FIgure 6: Time-dependent solubility of $\mathrm{CuO}$.

the adsorption of S2p. After the addition of $\mathrm{CuSO}_{4}, \mathrm{Cu} 2 \mathrm{p}$ was adsorbed on the surface of $\mathrm{CuO}$, and therefore the mole percentage of $\mathrm{Cu} 2 \mathrm{p}$ was increased. After adding both $\mathrm{CuSO}_{4}$ and $\mathrm{Na}_{2} \mathrm{~S}$, the adsorption of $\mathrm{S}$ and $\mathrm{Cu}$ was increased, indicating that the $\mathrm{Cu}$ can promote the adsorption of $\mathrm{S}$ on $\mathrm{CuO}$. With the addition of $\mathrm{FeCl}_{3}, \mathrm{Fe}$ adsorption can be clearly observed. When $\mathrm{Na}_{2} \mathrm{~S}$ and $\mathrm{FeCl}_{3}$ were both added, the adsorption of $\mathrm{S}$ was reduced and a lot of Fe were adsorbed on solid surface possibly because the $\mathrm{Fe}^{3+}$ was partially oxidized [29] and Fe-S compounds were produced. The results of XPS full spectra suggest that the copper ions can promote the adsorption and sulphidizing of sodium sulfide while iron ions do the opposite, which are consistent with the conclusion drawn from the flotation experiments.

Figures 9-11 show the fitting of Cu2p, S2p, and Fe2p absorption peaks. In Figure 9, besides two obvious peaks from $\mathrm{Cu} 2 \mathrm{p} 3 / 2$ and $\mathrm{Cu} 2 \mathrm{p} 2 / 1$, two side peaks with energy level splitting were also observed. After the addition of $\mathrm{Na}_{2} \mathrm{~S}$, as shown in Figure 10, two doublets fitted the measured spectrum. Sulfur, monosulfides, and polysulfides $[14,21]$ appeared in S2p peak, reflecting the existence of sulfur-rich environment on the $\mathrm{CuO}$ surface. The appearance of sulphate was because $\mathrm{Na}_{2} \mathrm{~S}$ can be easily oxidized in air, so it could always be detected by XPS. On the other hand, its existence in the figure is to compare with the sample 4 , in which $\mathrm{CuSO}_{4}$ was added, and sample 6, in which the $\mathrm{Fe}^{3+}$ should oxidize $\mathrm{S}^{2-}$ to sulphate. The presence of polysulfide on the $\mathrm{CuO}$ surface was beneficial to $\mathrm{CuO}$ hydrophobicity and facilitates the floatability [21,30-33]. In addition, the position of binding energy peak of $\mathrm{Cu}^{+}$and $\mathrm{Cu}^{2+}[34,35]$ was displaced, and peak area was changed, suggesting the formation of copper sulfide [36-38]. After the addition of $\mathrm{Na}_{2} \mathrm{~S}$ and $\mathrm{CuSO}_{4}$ at the same time, the change of the valence state and binding energy of S2p indicated the occurrence of redox reaction between $\mathrm{Cu} 2 \mathrm{p}$ and $\mathrm{S} 2 \mathrm{p}$, which promoted the formation of polysulfide compounds and increased the adsorption of Cu2p on S2p [39-42], leading to the increasing of the sulphidizing of $\mathrm{Na}_{2} \mathrm{~S}$. After the addition of $\mathrm{FeCl}_{3}$, it can be seen from Figure 11 that the peak of $\mathrm{Cu} 2 \mathrm{p}$ appeared among the peaks of $\mathrm{Fe} 2 \mathrm{p}$, which may have some interference 


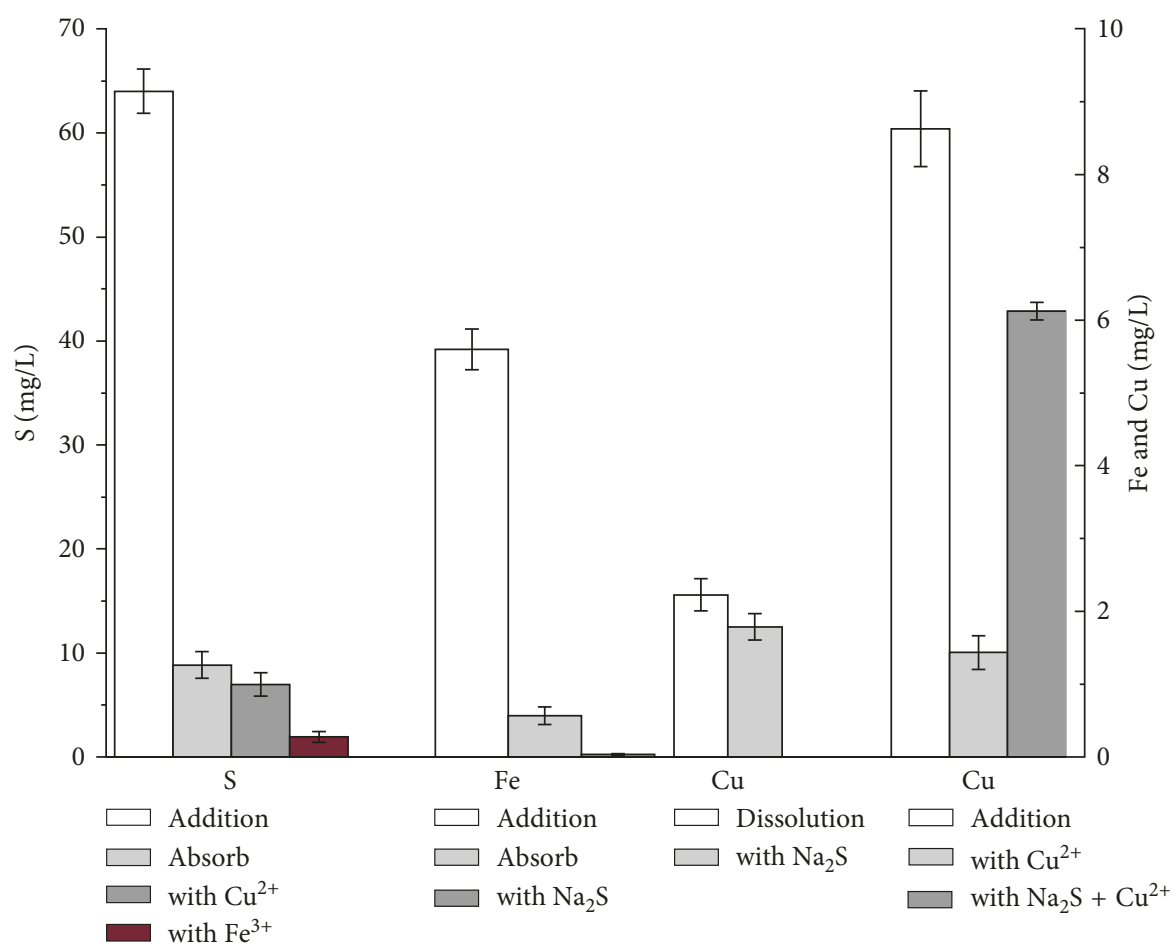

FIGURE 7: ICP results of the $\mathrm{CuO}$ solution with adsorbed ions.

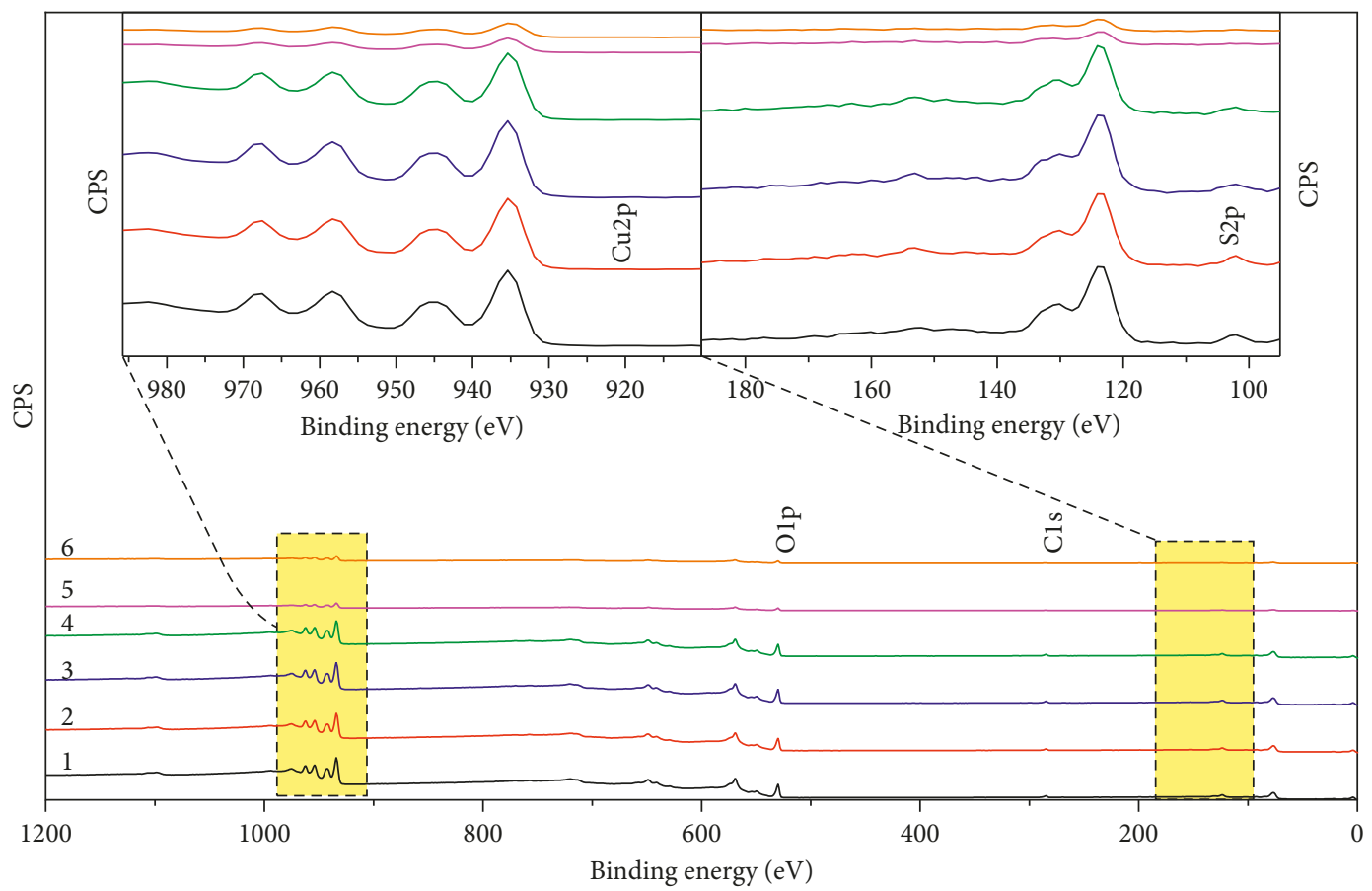

FIgURE 8: Comparison of $\mathrm{CuO}$ adsorption with and without different additions.

to the analysis of Fe2p peaks, but it does not influence the estimation of the effect of $\mathrm{Fe}^{3+}$ and $\mathrm{Fe}^{2+}$. The strong oxidative activity of $\mathrm{Fe}^{3+}$ can oxidize the $\mathrm{Cu}^{+}$ion and result in the change of the binding energy of $\mathrm{Cu}^{+}$. With the addition of $\mathrm{FeCl}_{3}$ and $\mathrm{Na}_{2} \mathrm{~S}$ at the same time, redox reaction occurred between $\mathrm{Fe}^{3+}$ and $\mathrm{S}^{2-}$ with strong reductivity, leading to the displacement of the binding energy of S2p with low valence state, and consequently the adsorption of S2p was reduced.

\section{Conclusions}

(1) The flotation results show that the $\mathrm{Cu}^{2+}$ has a good effect on the sulphidizing of copper oxide and can 
TABle 5: Atomic percentage (\%) of elements on $\mathrm{CuO}$ surface.

\begin{tabular}{|c|c|c|c|c|c|}
\hline Number & Samples & $\mathrm{Cu} 2 \mathrm{p}$ & O1p & $\mathrm{S} 2 \mathrm{p}$ & $\mathrm{Fe} 2 \mathrm{p}$ \\
\hline 1 & $\mathrm{CuO}$ & 45.01 & 54.99 & 0 & 0 \\
\hline 2 & $\mathrm{CuO}+\mathrm{Na}_{2} \mathrm{~S}$ & 44.97 & 53.76 & 1.27 & 0 \\
\hline 3 & $\mathrm{CuO}+\mathrm{CuSO}_{4}$ & 45.80 & 54.20 & 0 & 0 \\
\hline 4 & $\mathrm{CuO}+\mathrm{Na}_{2} \mathrm{~S}+\mathrm{CuSO}_{4}$ & 45.54 & 53.53 & 1.92 & 0 \\
\hline 5 & $\mathrm{CuO}+\mathrm{FeCl}_{3}$ & 43.31 & 45.73 & 0 & 11.62 \\
\hline 6 & $\mathrm{CuO}+\mathrm{FeCl}_{3}+\mathrm{Na}_{2} \mathrm{~S}$ & 44.68 & 42.25 & 1.04 & 11.43 \\
\hline
\end{tabular}

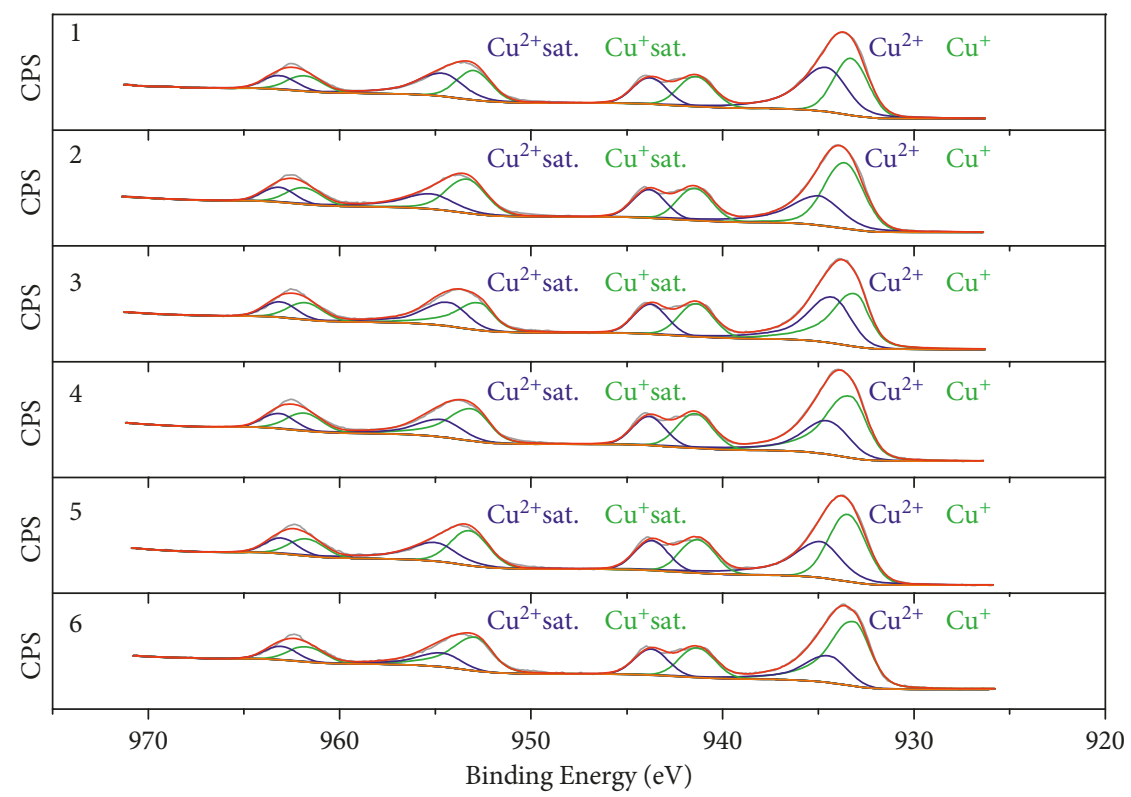

FIgURE 9: $\mathrm{Cu} 2 \mathrm{p}$ spectra of $\mathrm{CuO}$ adsorption with and without different additions.

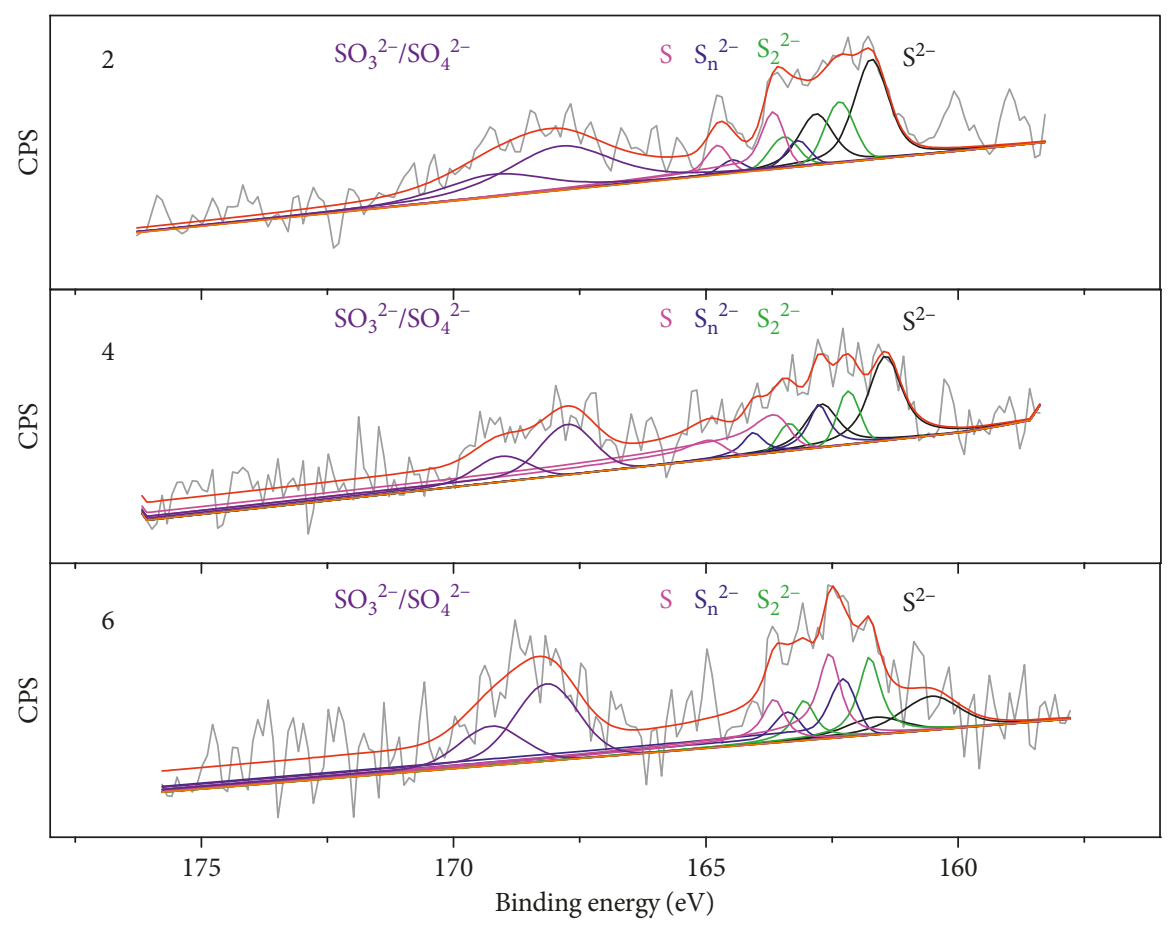

Figure 10: S2p Spectra of $\mathrm{CuO}$ adsorption with and without different additions. 


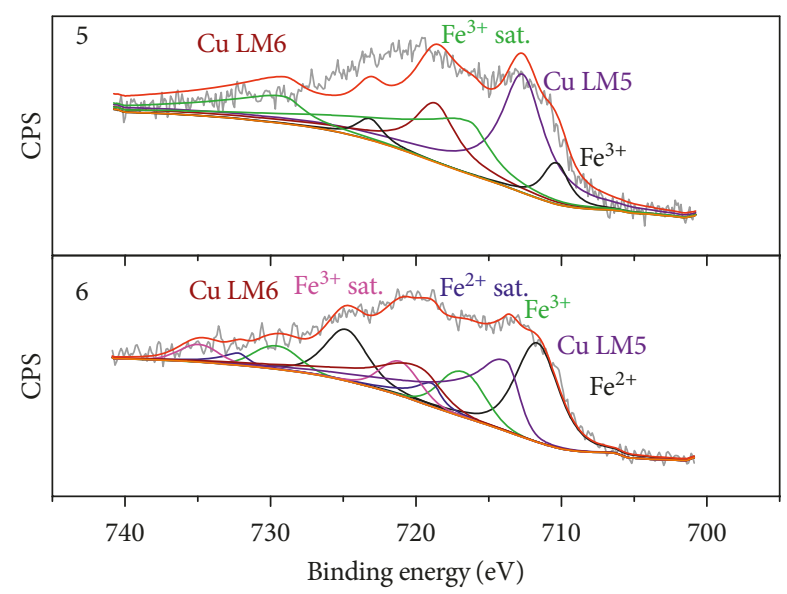

FIgURE 11: Fe2p spectra of $\mathrm{CuO}$ adsorption with and without different additions.

improve the recovery with the appropriate concentration. On the contrary, $\mathrm{Fe}^{3+}$ has certain depressing effect.

(2) Zeta potential results show that the $\mathrm{Cu}^{2+}$ enhances the surface potential because of covalent adsorption. $\mathrm{Fe}^{3+}$ increases the surface potential of $\mathrm{CuO}$ significantly because of the large amount of ferric hydroxide which begins to precipitate on the $\mathrm{CuO}$ surface earlier than in the solution, so the zeta potential will remain positive until the $\mathrm{pH}$ gets to the IEP of ferric hydroxide itself.

When $\mathrm{Na}_{2} \mathrm{~S}$ was added, the zeta potential became further negative because of sulfidization reaction. Corresponded well with the microflotation tests, addition $\mathrm{Na}_{2} \mathrm{~S}$ along with $\mathrm{Cu}^{2+}$ ions, the potential increased relatively to that of $\mathrm{CuO}$ but decreased in relation to $\mathrm{CuO}+\mathrm{Na}_{2} \mathrm{~S}$. This phenomenon demonstrated that the $\mathrm{Cu}^{2+}$ results in better sulfidization. On the opposite, $\mathrm{Fe}^{3+}$ ions increased relatively to that of $\mathrm{CuO}$ but decreased in relation to $\mathrm{CuO}+\mathrm{Na}_{2} \mathrm{~S}$.

(3) The results of ICP and XPS show that sodium sulfide is adsorbed on the surface in the form of sulfur, monosulfides, and polysulfides, and thus the sulfurrich environment is formed. The addition of $\mathrm{Cu}^{2+}$ changes the binding energy of sulfur and promotes the sulphidizing. The addition of $\mathrm{Fe}^{3+}$ can oxidize the sulfur ions and consequently reduce the adsorption. This indicated that the adsorption of iron ions on copper oxide is chemical adsorption.

\section{Conflicts of Interest}

The authors declare that they have no conflicts of interest.

\section{Authors' Contributions}

Qing-qing Pan and Hui-qing Peng conceived and designed the experiments. Qing-qing Pan performed the experiments. Qing-qing Pan and Hui-qing Peng analyzed the data. Qingqing Pan and Hui-qing Peng wrote the paper.

\section{References}

[1] J. Zhang, Y.-H. Qi, D.-L. Yan, and H.-C. Xu, "A new technology for copper slag reduction to get molten iron and copper matte," Journal of Iron and Steel Research, International, vol. 22, no. 5, pp. 396-401, 2015.

[2] H.-C. Gan, "Investigation and practicality of beneficiation for Daye Ruolanda furnace slag," Hunan Metallurgy, vol. 32, no. 4, pp. 28-34, 2004.

[3] H.-J. Huang, "A new technology for crystal phase regulating flotation of copper-containing slag," Nonferrous Metals, vol. 6, pp. 16-19, 2012.

[4] F. Jiang, H.-J. Huang, W. Sun, R.-Q. Liu, and Y. Xiong, "Comparative experimental research on flotation of copper from different copper slag," Nonferrous Metals, vol. 6, pp. 60-63, 2013.

[5] L. Liu, H.-J. Yan, J.-M. Zhou et al., "Mechanism of copper smelting process by oxygen bottom blowing and microanalysis of smelting products," Chinese Journal of Nonferrous Metals, vol. 22, no. 7, pp. 2116-2124, 2012.

[6] L. Y Chai, J.-X. Wu, Y.-J. Wu, C.-B. Tang, and W.-C. Yang, "Environmental risk assessment on slag and iron-rich matte produced from reducing-matting smelting of lead-bearing wastes and iron-rich wastes," Transaction of Nonferrous Metal Society of China, vol. 25, no. 10, pp. 3429-3435, 2015.

[7] A. Rozendaal and R. Horn, "Textural, mineralogical and chemical characteristics of copper reverb furnace smelter slag of the Okiep Copper District, South Africa," Minerals Engineering, vol. 52, pp. 184-190, 2013.

[8] K. C. Corin, M. Kalichini, C. T. O’Connor, and S. Simukanga, "The recovery of oxide copper minerals from a complex copper ore by sulphidisation," Minerals Engineering, vol. 102, pp. 15-17, 2017.

[9] P.-R. Wang, H.-X. Dai, G.-Y. Xu, and Q.-H. Hu, "Research and application status on activators of floating oxide copper ores," Mining \& Metallurgy, vol. 21, no. 1, pp. 15-17, 2012.

[10] S. Roy, A. Datta, and S. Rehani, "Flotation of copper sulphide from copper smelter slag using multiple collectors and their mixtures," International Journal of Mineral Processing, vol. 143, pp. 43-49, 2015.

[11] A. Jarosíkova, V. Ettler, M. Mihaljevi, B. Kríbek, and B. Mapani, "The $\mathrm{pH}$-dependent leaching behavior of slags from various stages of a copper smelting process: environmental implications," Journal of Environmental Management, vol. 187, pp. 178-186, 2017.

[12] R. O. James and T. W. J. Healy, "Adsorption of hydrolyzable metal ions at the oxide-water interface I: Co (II) adsorption on $\mathrm{SiO}_{2}$ and $\mathrm{TiO}_{2}$ as model systems," Journal of Colloid and Interface Science, vol. 40, no. 1, pp. 42-52, 1972.

[13] D. Fornasiero and J. Ralston, "Cu (II) and Ni (II) activation in the flotation of quartz lizardite and chlorite," International Journal of Miner Process, vol. 76, no. 1-2, pp. 75-81, 2005.

[14] Q.-C. Feng, W.-J. Zhao, S.-M. Wen, and Q.-B. Cao, "Copper sulfide species formed on malachite surfaces in relation to flotation," Journal of Industrial and Engineering Chemistry, vol. 48, pp. 125-132, 2017.

[15] M.-A. Wei and C.-Y. Sun, "Influence of metal cations in pulp to chalcopyrite and galena floatability," Nonferrous Metals, vol. 60, no. 2, pp. 92-95, 2008.

[16] Z.-T. Yuan, Q.-D. Zhang, and J.-T. Liu, "Influence and mechanism of metal ions on flotation of molybdenite," Journal of Northeastern University, vol. 37, no. 7, pp. 10131016, 2016.

[17] J.-S. Deng, S.-M. Wen, J. Liu, D.-D. Wu, and Q.-I. Feng, "Adsorption and activation of copper ions on chalcopyrite 
surfaces: a new viewpoint of self-activation," Transaction of Nonferrous Metal Society of China, vol. 24, no. 12, pp. 39553963, 2014.

[18] J.-S. Deng, S.-M. Wen, Y.-J. Xian, J. Liu, and S.-J. Bai, “New discovery of unavoidable ions source in chalcopyrite flotation pulp: fluid inclusions," Minerals Engineering, vol. 42, pp. 22-28, 2013.

[19] Q.-C. Feng, S.-M. Wen, W.-J. Zhao, J.-S. Deng, and Y.-J. Xian, "Adsorption of sulfide ions on cerussite surfaces and implications for flotation," Applied Surface Science, vol. 360, pp. 365372, 2016.

[20] J. Zhang, W.-Q. Wang, J. Liu, Y. Huang, Q.-M. Feng, and Z. Hong, "Fe (III) as an activator for the flotation of spodumene, albite, and quartz minerals," Minerals Engineering, vol. 61, pp. 16-22, 2014.

[21] Q.-C. Feng and S.-M. Wen, "Formation of zinc sulfide species on smithsonite surfaces and its response to flotation performance," Journal of Alloys and Compounds, vol. 709, pp. 602608, 2017.

[22] Q.-C. Feng, S.-M. Wen, J.-S. Deng, and W.-J. Zhao, “DFT study on the interaction between hydrogen sulfide ions and cerussite (110) surface," Applied Surface Science, vol. 396, pp. 920-925, 2017.

[23] Q.-M. Feng, G.-S. Liu, Z.-J. Yu, Y.-P. Lu, L.-M. Ou, and G.-F. Zhang, "Influence and mechanism of ferric and ferrous ions on flotation of talc," Journal of Central South University of Science and Technology, vol. 37, no. 3, pp. 476-480, 2006.

[24] G.-F. Zhang, S.-P. Jiang, Q.-M. Feng, and B.-F. Zhang, "Surface sulfidization of zinc minerals in solution system," Journal of Central South University of Science and Technology, vol. 48, no. 4, pp. 851-859, 2017.

[25] Q.-C. Feng, S.-M. Wen, and W.-J. Zhao, "Contribution of chloride ions to the sulfidization flotation of cerussite," Minerals Engineering, vol. 83, pp. 128-135, 2015.

[26] D.-Z. Wang and Y.-H. Hu, Solution Chemistry of Flotation, Hunan Science and Technology Press, Changsha, China, 1988.

[27] Z.-W. Yan, H.-L. Liu, and S.-X. Li, "Study on several problems of hydrochemistry," Shandong Land and Resources, vol. 29, no. 10-11, pp. 103-106, 2013.

[28] Z.-W. Yan and Z.-W. Zhang, "The effect of chloride on the solubility of calcite and dolomite," Hydrogeology and Engineering Geology, vol. 1, pp. 113-118, 2009.

[29] X. Wu, L. Lv, and D.-Y. Xu, "Experimental investigation of the reaction of $\mathrm{S}^{2-}$ and $\mathrm{Fe}^{3+}$ in alkaline medium," Chinese Journal of Chemical Education, vol. 5, pp. 66-67, 2009.

[30] R. S. C. Smart, W. M. Skinner, and A. R. Gerson, "XPS of sulphide mineral surfaces: metal-deficient, polysulphides, defects and elemental sulphur," Surface and Interface Analysis, vol. 28, no. 1, pp. 101-105, 1999.

[31] J. Liu, S.-M. Wen, Y.-J. Xian, and J.-S. Deng, "Dissolubility and surface properties of a natural sphalerite in aqueous solution," Minerals Metal Process, vol. 29, pp. 113-120, 2012.

[32] X.-M. Chen, Y.-J. Peng, and D. Bradshaw, "The separation of chalcopyrite and chalcocite from pyrite in cleaner flotation after regrinding," Minerals Engineering, vol. 58, pp. 64-72, 2014.

[33] S. He, D. Fornasiero, and W. Skinner, "Correlation between copper-activated pyrite flotation and surface species: effect of pulp oxidation potential," Minerals Engineering, vol. 18, no. 12, pp. 1208-1213, 2005.

[34] F.-X. Li, H. Zhong, H.-F. Xu, H. Jia, and G.-Y. Liu, "Flotation behavior and adsorption mechanism of a-hydroxyoctyl phosphinic acid to malachite," Minerals Engineering, vol. 71, pp. 188-193, 2015.
[35] G.-Y. Liu, Y.-G. Huang, X.-Y. Qu, J.-J. Xiao, X.-L. Yang, and $\mathrm{Z}$.-H. Xu, "Understanding the hydrophobic mechanism of 3-hexyl-4-amino-1, 2,4-triazole-5-thione to malachite by ToF-SIMS, XPS, FTIR, contact angle, zeta potential and micro-flotation," Colloids and Surfaces A: Physicochemical and Engineering Aspects, vol. 503, pp. 34-42, 2016.

[36] G. A. Rober, L. H. Sarah, A. B. David, and X. P. S. Synchrotron, "NEXAFS, and ToF-SIMS studies of solution exposed chalcopyrite and heterogeneous chalcopyrite with pyrite," Minerals Engineering, vol. 23, no. 11-13, pp. 928-936, 2010.

[37] J. Mielczarski, "XPS study of ethyl xanthate adsorption on oxidized surface of cuprous sulfide," Journal of Colloid and Interface Science, vol. 120, no. 1, pp. 201-209, 1987.

[38] W. M. Skinner, C. A. Prestidge, and R. S. C. Smart, "Irradiation effects during XPS studies of $\mathrm{Cu}(\mathrm{I} 1)$ activation of zinc sulphide," Surface and Interface Analysis, vol. 24, no. 9, pp. 620-626, 1996.

[39] S. Liu, G.-Y Liu, H. Zhong, and X.-L. Yang, "The role of HABTC's hydroxamate and dithiocarbamate groups in chalcopyrite flotation," Journal of Industrial and Engineering Chemistry, vol. 52, pp. 359-368, 2017.

[40] P. Velasquez, J. R. Ramos-Barrado, R. Cordova, and D. Leinen, "XPS analysis of an electrochemically modified electrode surface of natural enargite," Surface and Interface Analysis, vol. 30, pp. 149-153, 2000.

[41] L. H. Sarah, E. T. Joan, F. Daniel, and R. G. Andrea, "The evolution of surface layers formed during chalcopyrite leaching," Geochimica et Cosmochimica Acta, vol. 70, no. 17, pp. 4392-4402, 2006.

[42] S. C. Termes, A. N. Buckley, and R. D. Gillard, " $2 p$ electron binding energies for the sulfur atoms in metal polysulfides," Inorganica Chimica Acta, vol. 126, no. 1, pp. 79-82, 1987. 


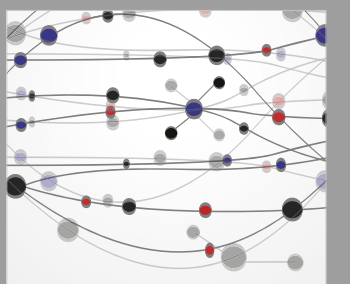

The Scientific World Journal
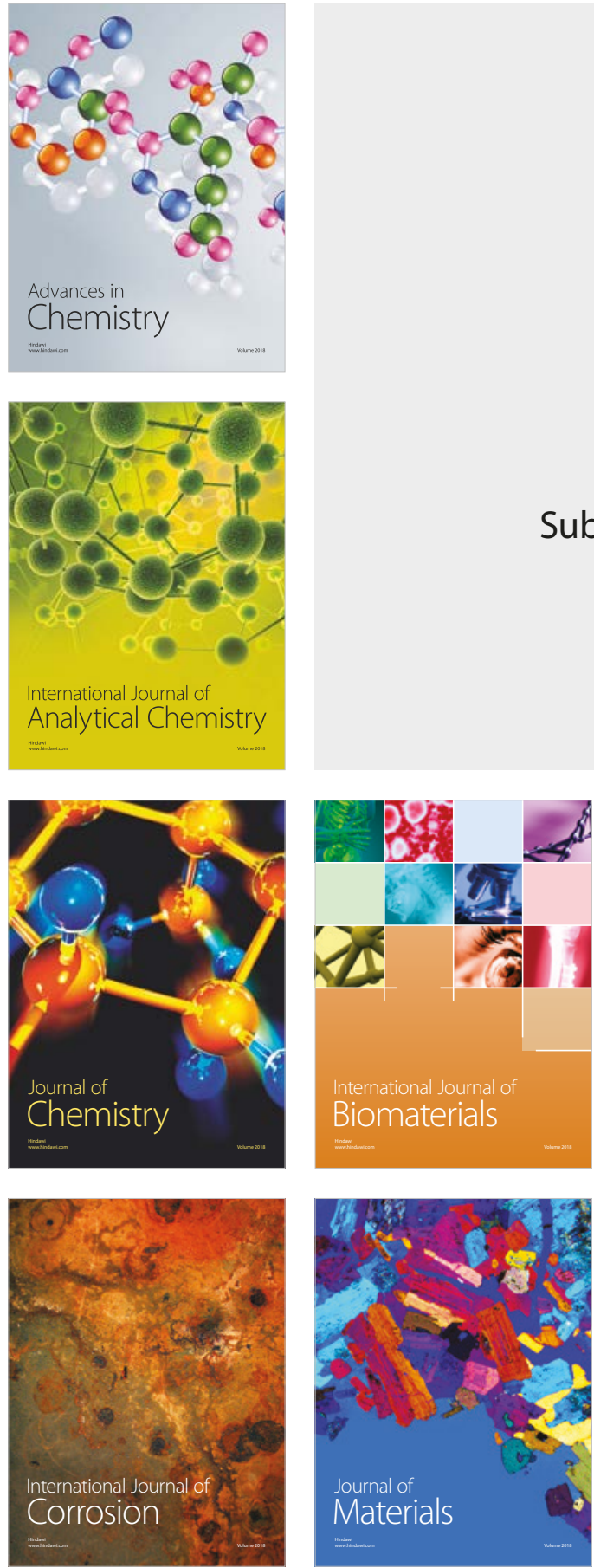

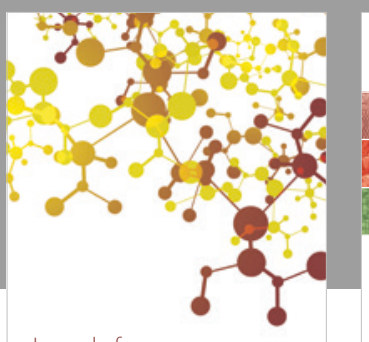

Journal of

Applied Chemistry
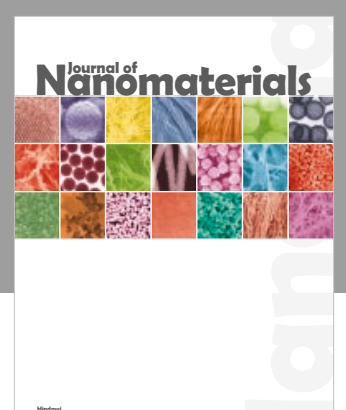

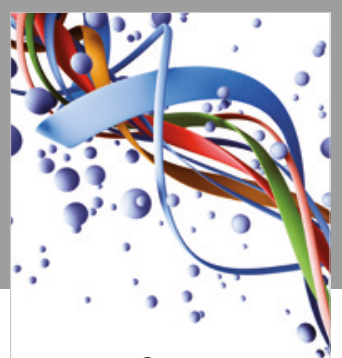

Scientifica

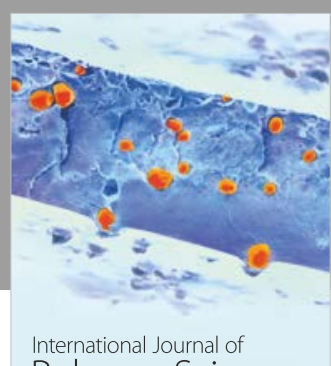

Polymer Science

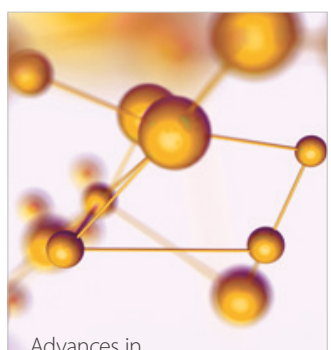

Physical Chemistry
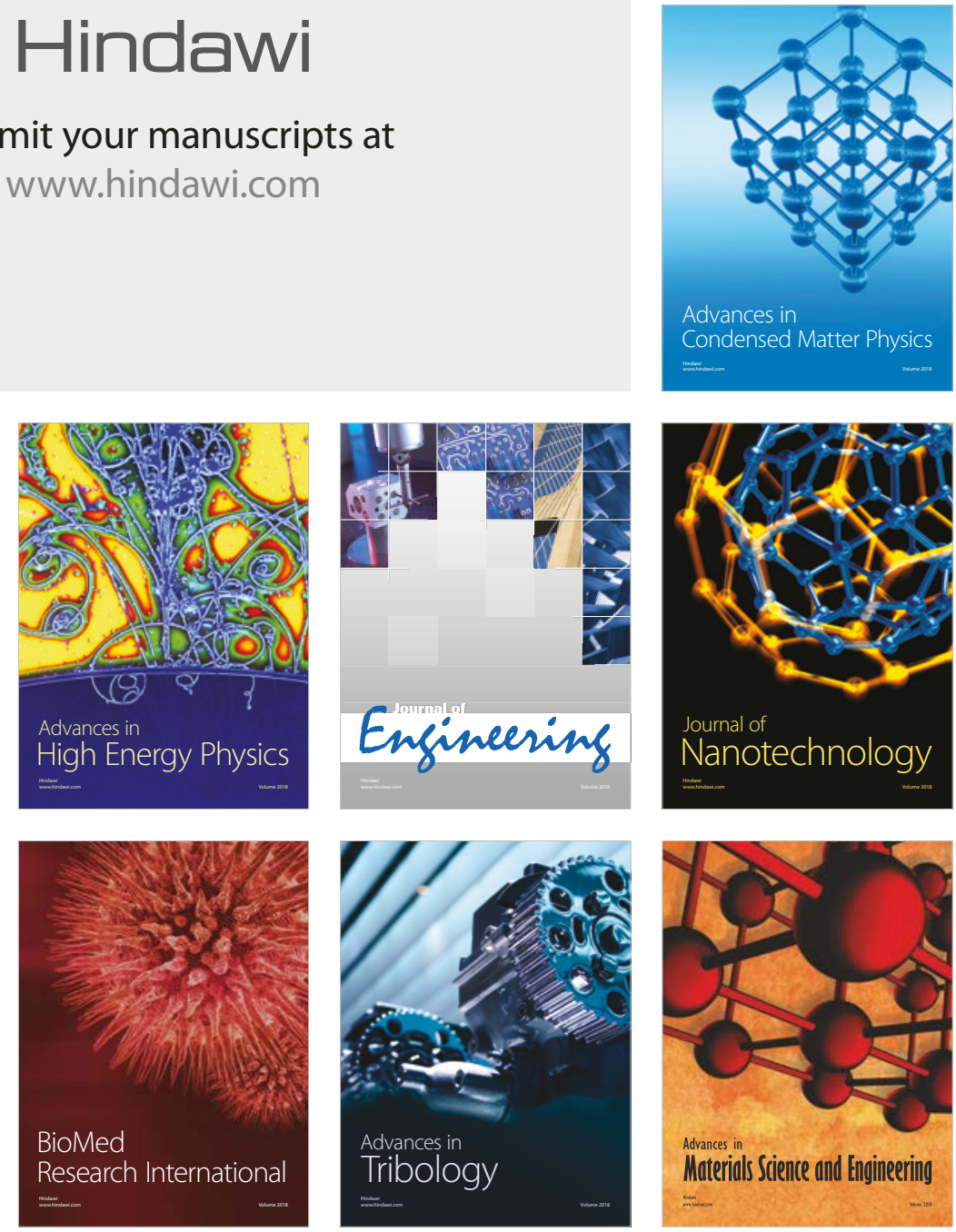